\title{
Extração e observação de molécula de DNA - Ferramenta para auxiliar no ensino de Biologia
}

DNA molecule extraction and observation - Tool to assist in Biology teaching

Efigênia Monteiro Tosta ${ }^{1}$, Andreia Barcelos Passos Lima Gontijo ${ }^{2}$, Viviana Borges Corte 3

${ }^{1}$ Programa de Pós-Graduação em Rede em Ensino de Biologia (PROFBIO), Universidade Federal do Espírito Santo, São Mateus, Espírito Santo, Brasil.

${ }^{2}$ Universidade Federal do Espírito Santo, Departamento de Ciências Agrárias e Biológicas, São Mateus, Espírito Santo, Brasil.

${ }^{3}$ Universidade Federal do Espírito Santo, Departamento de Ciências Biológicas, Vitória, Espírito Santo, Brasil.

Autor para correspondência: Efigênia Monteiro Tosta

EEEFM Aflordizio de Carvalho da Silvania

Rua Sete de Setembro, 99, apto 303, CEP 29.015-000, Vitória, Espírito Santo, Brasil

Tel: +55 27 99279-8846

Email efigeniamonteirotosta@gmail.com

Submetido em 21/12/2020

Aceito em 21/12/2020 


\title{
RESUMO
}

O trabalho trata-se de uma proposta de atividade investigativa sobre o tema Biologia Molecular para as aulas de Biologia do ensino médio, tendo como objetivo identificar estruturas celulares relacionadas à genética e a hereditariedade, investigando a existência e a função do DNA através de experimentação simples. A atividade proporcionou a participação e integração de todos os alunos, observando-se maior aproximação entre o conhecimento teórico e a experimentação. Os alunos relataram que a atividade despertou curiosidade e interesse, favorecendo o aprendizado de todos.

Palavras-chave: Biologia. Biologia Molecular. Genética. Atividade Investigativa. Ensino.

\begin{abstract}
The work is a proposal for an investigative activity on the theme Molecular Biology for high school Biology classes with the objective of identifying cell structures related to genetics and heredity, investigating the existence and function of DNA through simple experimentation. The activity provided the participation and integration of all students, observing a greater approximation between theoretical knowledge and experimentation. The students reported that the activity aroused curiosity and interest, favoring everyone's learning.
\end{abstract}

Keywords: Biology. Molecular biology. Genetics. Investigative Activity. Teaching.

Health and Biosciences, v.1, n.3, Dez. 2020

Disponível em: https://periodicos.ufes.br/healthandbiosciences 


\section{INTRODUÇÃO}

Para alcançar o efetivo aprendizado, os docentes enfrentam um grande desafio, que é superar a passividade dos alunos nas salas de aula, que se comportam como meros observadores de um conteúdo apresentado pelo professor de maneira expositiva.

Este ensino vertical, com a transmissão do conhecimento do professor para o aluno faz com que a aprendizagem se processe de forma mecânica, em que este não é levado a pensar e nem a desenvolver seu pensamento independente e criativo (NEVES et al., 2010). Essa abordagem promove o distanciamento e dissociação do conteúdo em relação à vida cotidiana, causando desinteresse por parte dos alunos e desfavorecendo o processo aprendizagem (LONGO, 2012).

O ensino de Genética implica na capacidade de transformar conceitos abstratos, como gene e DNA, de imagens ilustrativas em conseguir interligar conteúdos, por exemplo, meiose e formação de gametas. Então, o professor precisa utilizar diferentes metodologias para que seu discurso seja compreendido (KRASILCHIK, 2008). Temas relacionados à Genética estão presentes nos mais variados momentos de nossas vidas, desde a manipulação vegetal com o objetivo de maior produção de alimentos até a pesquisa com células-tronco que buscam desenvolver tratamentos eficazes contra doenças degenerativas, como distrofias musculares (BARNI, 2010; ZATZ, 2012).

A experimentação na escola, associada a uma exposição teórica eficiente, mantém ativo o interesse dos alunos pelas aulas, envolvem todos os estudantes no processo de investigação científica e criam subsídios para o desenvolvimento da capacidade de resolver problemas a partir do conhecimento dos princípios básicos das disciplinas (KRASILCHIK, 2008).

Dentro deste contexto faz-se necessária a utilização de metodologia diferenciada, de cunho investigativo, que engloba o campo procedimental e atitudinal. No âmbito procedimental, implica em não transmitir para as próximas gerações a ideia de uma Ciência pronta e acabada, mas prover a aculturação científica que é o principal pressuposto da socialização do conhecimento. No campo atitudinal compromete-se com a tomada de decisões fundamentais e críticas sobre o desenvolvimento científico e tecnológico das sociedades (CARVALHO, 2003).

A Biologia, como Ciência, tem como objetivo o estudo da vida e dos seres vivos, bem como seus fenômenos e origem. A Genética dedica-se ao estudo dos genes, os quais contêm as 
informações biológicas que devem ser copiadas com precisão para ser transmitidas às próximas gerações. Compreender a molécula do DNA (ácido desoxirribonucleico) é de grande importância para a formação dos conhecimentos consolidados dos estudantes sobre a estruturação da vida.

O DNA é um tipo de ácido nucleico que possui destacada importância por armazenar a informação genética dos seres vivos. Para manter sua função de armazenamento de informação o DNA deve ser capaz de fazer mais do que simples cópias de si mesmo, antes de cada divisão celular. Ele deve, também, expressar sua informação, usando-a para guiar a síntese de outras moléculas na célula (ALBERTS et al., 2004).

A estrutura da molécula de DNA foi elucidada por James Watson e Francis Crick, em 1953, consagrando a descoberta da estrutura de dupla hélice das duas longas fitas de DNA que se enrolam. A informação genética é mantida em uma sequência linear de nucleotídeos no DNA. Cada molécula de DNA é uma dupla hélice formada por duas fitas complementares de nucleotídeos que são mantidas unidas por pontes de hidrogênio entre os pares de bases G-C e A-T. A duplicação da informação genética ocorre por replicação do DNA. Nesse processo, as duas fitas de um DNA dupla hélice são separadas, e cada uma serve como um molde para a síntese de uma nova sequência complementar. A informação genética é lida e processada em duas etapas: primeiro, na transcrição, os segmentos de uma sequência de DNA são usados para guiar a síntese de moléculas de RNA; depois, na tradução, as moléculas de RNA são usadas para guiar a síntese de moléculas de proteínas. Nos eucariotos o DNA está localizado no núcleo celular (ALBERTS et al., 2004).

Portanto, compreender o papel do DNA, bem como sua estrutura, nos permite entender os processos que garantem a transferência de informação genética entre os indivíduos, elucidando assim, diversos fenômenos biológicos dos seres vivos, como mitose, meiose e formação de gametas, temas que despertam grande curiosidade nos alunos.

\section{OBJETIVOS}

$\checkmark$ Identificar estruturas celulares relacionadas à genética e a hereditariedade, através de um experimento simples, utilizando material do cotidiano deles (banana).

$\checkmark$ Investigar a existência e a função do DNA através de sua extração, e apresentar as funções dos reagentes utilizados para a experimentação.

Health and Biosciences, v.1, n.3, Dez. 2020

Disponível em: https://periodicos.ufes.br/healthandbiosciences 
$\checkmark$ Utilizar a experimentação como etapa de investigação e estratégia motivadora do aprendizado.

\section{METODOLOGIA}

\section{Materiais utilizados}

Os materiais utilizados foram distribuídos em igual quantidade para grupos com cinco alunos:

- banana madura;

- saco plástico resistente;

- papel filtro (usados para coar café);

- vidro vazio de maionese com tampa;

- detergente doméstico (neutro);

- sal de cozinha;

- álcool absoluto gelado;

- colher de sopa;

- água;

- copo de vidro.

\section{Desenvolvimento}

O desenvolvimento da atividade investigativa se deu em cinco etapas que podemos descrever do seguinte modo:

\section{Etapa 1: Problematização}

A problematização foi iniciada na sala de aula com o seguinte questionamento aos alunos: “Onde o DNA está presente e como podemos observá-lo?”. Continuamos a estimular a capacidade investigativa dos alunos com outras perguntas norteadoras e instigantes sobre DNA, tais como:

1- O que é o DNA?

2- Como funciona o DNA?

3- Os gêmeos têm o DNA idêntico?

4- O que são mutações e como elas surgem?

5- Por que dizem que somos parentes dos macacos?

6- Será possível clonar um dinossauro?

Health and Biosciences, v.1, n.3, Dez. 2020

Disponível em: https://periodicos.ufes.br/healthandbiosciences 
Após o debate de ideias foi solicitado aos alunos que escrevessem suas hipóteses justificadas sobre tais questões:

"O DNA guarda o material genético com as informações".

"Faz copias idênticas"

"Alguns gêmeos iguais têm o mesmo DNA, os diferentes têm DNA diferente"

"Mutações são erros que ocorrem no DNA"

\section{Etapa 2: Levantamento de hipóteses}

Com base nas respostas e hipóteses elaboradas pelos alunos, nesta etapa, realinhamos os seus conhecimentos prévios com o saber científico apresentado através de imagens, slides e animações, com a utilização de conteúdo disponível na literatura, através de linguagem apropriada e de fácil compreensão. Foi apresentado um histórico sobre a descoberta do DNA e a elucidação da sua composição química.

\section{Etapa 3: Prática para extração de DNA}

Para a experimentação foi entregue a cada grupo de alunos um roteiro com orientações, conforme descrição abaixo:

1. Retirar a casca da banana.

2. Colocar a banana dentro de um saco plástico e macerar, pressionando a banana com os dedos até obter uma pasta quase homogênea. Depois transferir a pasta de banana para um copo.

3. Em outro copo misturar seis colheres de sopa de água, duas colheres de sopa de detergente e uma colher de sal de cozinha. Mexer bem com o bastão de vidro, porém devagar para não fazer espuma.

4. Colocar cerca de três colheres da mistura de água, sal e detergente sobre o macerado de banana. Misturar levemente com o bastão.

5. Deixar o conteúdo em repouso por quinze minutos e mexer, de vez em quando, levemente com o bastão de madeira.

6. Colocar o papel filtro sobre um copo limpo e passar a mistura pelo papel filtro para retirar pedaços que restaram.

7. Colocar metade do líquido peneirado em um copo transparente (colocar apenas cerca de 3 dedos no fundo do copo).

Health and Biosciences, v.1, n.3, Dez. 2020

Disponível em: https://periodicos.ufes.br/healthandbiosciences 
8. Por último, despejar delicadamente (pela parede do copo), sobre a solução, dois volumes de álcool comum. Aguardar cerca de 3 minutos para o DNA começar a precipitar na interfase.

\section{Etapa 4: Pesquisa para os alunos}

Depois da realização da experimentação, apresentamos uma série de estímulos na forma de um questionário com o título “Questões para Pesquisar”. As perguntas foram:

1. Quais são as principais etapas para se conseguir a extração de DNA?

2. Considerando o protocolo usado, em que etapa ocorreu o rompimento das membranas plasmáticas das células? Explique.

3. Quais são as funções dos reagentes, detergente, sal e álcool, usados na experiência?

4. Por que macerar mecanicamente a banana?

5. Se não conseguimos ver o DNA de uma célula nem em microscópio ótico, como conseguimos visualizar nesta prática que a extração de DNA funcionou a olho nu?

6. Em que tipo de frutas pode realizar estes experimentos?

\section{Etapa 5: Discussão de resultados}

Nas duas primeiras etapas a apresentação do conteúdo possuía um caráter "teóricoproblemático" que não despertou muito entusiasmo nos alunos. Esse quadro mudou durante a realização da atividade na etapa 3 , momento em que os alunos se apresentaram mais livres e abertos para debater e tirar dúvidas.

Uma das discussões apresentadas pelos alunos veio do seguinte apontamento: "Nós vimos um emaranhado de fios, não o DNA tridimensional que vemos em imagens". Essa afirmação permitiu discussões sobre o modelo de dupla hélice do DNA: o modelo de fita dupla hélice não pode ser observado com este método devido ao diâmetro excessivamente pequeno da molécula de DNA (2 manômetros), sendo esta forma somente visível com a utilização de microscopia eletrônica. Um dos métodos para observar a estrutura do DNA consiste na técnica de amplificação, denominada reação em cadeia pela polimerase (PCR em tempo real ou no gel de eletroforese), que irá permitir a replicação in vitro, em larga escala, apenas do segmento de DNA de interesse de estudo.

O método utilizado na escola requer o uso de detergente líquido para desnaturar as

Health and Biosciences, v.1, n.3, Dez. 2020

Disponível em: https://periodicos.ufes.br/healthandbiosciences 
membranas lipídicas e água com sal para neutralizar o DNA, que precipita ao adicionar álcool gelado, pois estará menos solúvel em solução alcoólica, proporcionando a visão de um emaranhado de moléculas de DNA, além de restos de células e organelas, o que enriqueceu ainda mais o debate.

O resultado foi debatido com a delimitação do tema "extração de DNA de células eucariontes" o qual os alunos compreenderam que se dá em três fases:

a) Ruptura das células;

b) Liberação de constituintes celulares (organelas e moléculas);

c) Precipitação de DNA.

\section{PONTOS INVESTIGATIVOS DA ATIVIDADE}

Ao responderem as questões norteadoras discutidas na primeira etapa e as do questionário "Questões Para Pesquisar", da etapa 4, os estudantes apresentaram alguns caminhos para responder ao problema da investigação. As pesquisas nos livros e principalmente na internet, bem como o experimento realizado, despertaram curiosidade e permitiram que ao final os alunos fossem capazes de confirmar ou rejeitar suas hipóteses iniciais sobre o assunto. Algumas hipóteses foram confirmadas, precisando apenas de melhorar a escrita de forma estruturada. Outras, como a funcionalidade, foi necessário rejeitar e reescrever após pesquisa e experimentos. Quanto às mutações, apesar de descreverem como erros não sabiam como ocorriam.

Foi observado na etapa de extração maior envolvimento, disposição e curiosidade dos alunos, confirmando que a aula prática estimula o aluno a ser agente do seu próprio aprendizado, constatando-se, assim, que a união de aulas práticas e teóricas, no ensino de Biologia, é muito importante para um ensino mais efetivo.

\section{CONSIDERAÇÕES}

A atividade proporcionou a participação e integração de todos os alunos, observando-se que entre eles surgiu uma maior aproximação entre o conhecimento teórico e a experimentação. Observamos debates, troca de informações, revisão de posições ao longo dos trabalhos, sendo um processo que buscou privilegiar a autonomia dos estudantes e com isso obtivemos resultado

Health and Biosciences, v.1, n.3, Dez. 2020

Disponível em: https://periodicos.ufes.br/healthandbiosciences 
muito produtivo.

Os alunos relataram que a atividade despertou curiosidade e interesse, favorecendo o aprendizado de todos.

Sem dúvida, as aulas práticas planejadas dentro de uma abordagem investigativa, tal como preconizado por Carvalho (2003), são instrumentos didáticos eficientes para o ensinoaprendizagem de Genética. Mesmo com algumas dificuldades, como a falta de laboratórios de ciências, superar essas limitações com adoção de procedimentos experimentais simples e que possam ser adaptados à realidade da escola, ajudam na melhoria da qualidade da educação básica.

\section{AGRADECIMENTOS}

O presente trabalho foi realizado com o apoio da Coordenação de Aperfeiçoamento de Pessoal de Nível Superior - Brasil (CAPES) - Código de financiamento 001.

\section{REFERÊNCIAS BIBLIOGRÁFICAS}

1. ALBERTS B, JOHNSON A, LEWIS J, RAFF M, ROBERTS K, WALTER P. Biologia molecular da célula, 4.ed., Porto Alegre: Artmed, 2004, 1549p.

2. BARNI GS. A importância e o sentido de estudar genética para estudantes do terceiro ano do ensino médio em uma escola da rede estadual de ensino em Gaspar (SC). Dissertação (Mestrado em Ciências Naturais e Matemática), Universidade Regional de Blumenau, Blumenau, 2010, 184f.

3. CARVALHO AMP, AZEVEDO MCPS, NASCIMENTO VB, CAPPECHI MCM, VANNUCCHI AI, CASTRO RS, PIETROCOLA M, VIANNA DM, ARAÚJO RS. Ensino de Ciências: Unindo a Pesquisa e a Prática, São Paulo: Cengage Learning, 2003, 165p.

4. KRASILCHIK M. Prática de Ensino de Biologia, São Paulo: Editora da Universidade de São Paulo, 2008, 200p.

5. LONGO VCC. Vamos jogar? Jogos como recursos didáticos no ensino de Ciências e Biologia, São Paulo: FCC/SEP, p.129-157, 2012. 
6. NEVES MA, ARAÚJO KCM, SEREJO MTT, ROJAS MOI, OLIVEIRA MM. Influência dos jogos como atividades lúdicas no curso de formação de professores em Química do IFMA. In: XV Encontro Nacional de Ensino de Química. Anais, Brasília, DF, 2010.

7. ZATZ M. Genética: a escolha que nossos avós não faziam. São Paulo: Editora Globo, 2012, $202 p$. 